\section{Food safety knowledge, attitudes, and practices of food handlers at kitchen premises in the Port ' $X$ ' area, North Jakarta, Indonesia 2018}

\author{
Muharnis Supriyani Putri, \\ Dewi Susanna ${ }^{2}$
}

${ }^{1}$ Master Program in Public Health

Sciences, and ${ }^{2}$ Department of

Environmental Health, Faculty of Public

Health, Universitas Indonesia, Indonesia

\begin{abstract}
Improper food handling can be a major cause of food contamination. To prevent food contamination, the food handler should have good knowledge, display a positive attitude, and practice proper food handling practices. This study aimed to evaluate the food safety and personal hygiene knowledge, attitudes, and practices of food handlers at kitchen premises in the Port ' $\mathrm{X}$ ' area in North Jakarta, Indonesia. This study uses a cross-sectional design. The research was conducted in April 2018 and May 2018. Data were collected from 72 food handlers from kitchens located in the Port ' $\mathrm{X}$ ' area in North Jakarta. Data collection was performed through interviews and observations, using questionnaires and checklists as research instruments. The results show a significant correlation between the level of knowledge about food safety and the attitude of food handlers ( $p=0.01$ ), and attitude scores were significantly higher among food handlers who reported attending a previous food safety training course $(p=0.002)$ with $(r=0.302)$ it means a weak uphill (positive) linear relationship attitude scores and training that food handlers attended. This study found a significant relationship between the knowledge and attitude of food handlers, but there was no significant relationship between knowledge or attitude and food handling practices. Thus, it is recommended that training activities for food handlers be held regularly, as the food safety knowledge obtained from training or courses can translate into the improvement of attitudes and food handling practices.
\end{abstract}

\section{Introduction}

Food safety is one of the most important issues in public health, and it contributes significantly to the cost of health care (Scallan and Hoekstra, 2011). Globally, it is estimated that 600 million people become ill, 549 million suffer from diarrheal disease, and 420,000 die each year after eating contaminated food (Kirk, 2015) (World Health Organization, 2015). Improper food handling by food handlers during food production processes - such as cooking, storing, and serving food - can play a major role in food contamination that develops into foodborne disease outbreaks (AnsariLari, 2010; Clayton, Griffith and Peters, 2002; Egan, Raats, \& Grubb, 2007; EFSA, 2010; Zanin and Cunha, 2017. Hence, food handler participation is important in foodborne disease prevention (Bou-Mitri, Mahmoud and El Gerges, 2018; Lee, Halim and Thong, 2017; Medeiros, Hillers and Chen, 2004; Sani and Siow, 2014.

Good knowledge and a positive attitude among the food handlers and proper food handling practices can help control the foodborne disease occurrence in some circumstances (Angelillo, Viggiani and Rizzo, 2000; Sharif and Al-Malki, 2010. In addition to good knowledge and positive attitudes regarding food safety, socio-demographic conditions, such as the level of education and food safety training attended by food handlers, have an important role in encouraging food handlers to implement proper food handling practices (Al-Shabib and Mosi, 2016; Sani and Siow, 2014).

Port ' $\mathrm{X}$ ', located in North Jakarta, is the largest and busiest port in Indonesia. This port serves as the main gateway for exports and imports in Indonesia. In addition to the export and import of goods, the ports are also busy with human foot traffic from ships (Arnita, 2014). Since the port is a gateway for humans and goods, foodborne diseases can easily spread in ports. The ' $\mathrm{X}$ ' Port Health Office has the main duty to prevent the entry and exit of infectious diseases that can become a Public Health Emergency of International Concern (PHEIC) (Kemenkes RI, 2011). Furthermore, based on Permenkes No. 2348/MENKES/PER/IX/2011, it functions to prevent the outbreak of diseases, carry out epidemiological surveillance and quarantine services, prevent the entry and exit of infection, control the impact of environmental health, regulates health services, Drugs, Food, Cosmetics, carryout Medical Devices, and Addictive (Indonesian: Obat, Makanan, Kosmetik, Bahan Aditif abbreviated as $O M K A B A$ ) Surveillance, offers protection against new and re-emergence diseases, bioterrorism, and biological, chemical and radiation security in the work area of airports, ports, and land borders of the State.

They are four working areas under supervised Port Health Office Tanjung
Correspondence: Dewi Susanna, Department of Environmental Health, Faculty of Public Health, Universitas Indonesia, Kampus UI Depok, Jawa Barat 16424, Indonesia.

Tel.: +62 217863479 - Fax: +62 217863479

E-mail: dsusanna@ui.ac.id; dsusanna2@ yahoo.com

Key words: Food handlers, Food safety knowledge, Attitude, Practice, Port.

Acknowledgments: The authors acknowledge The Directorate of Reseacrh and Community Engagement Universitas Indonesia for providing the source of funding for publishing this article through the program "Hibah Publikasi Internasional Terindeks untuk Tugas Akhir Mahasiswa (Hibah PITTA). The authors also would like to thank to MS. Rusyda Ihwani Tantia Nova for giving any comments in for improvement this manuscript.

Conflict of interest: The authors declare no potential conflict of interest.

Contributions: MSP: designed the idea, formulation research goals and aims, formal data analysis, interpretation; wrote the initial draft of manuscript. DS: developed or designed of methodology; creation of models, finalized the published work and acquisitioned of the financial support for the project leading to this publication.

Funding: This research supported by the grant from the Directorate of Research and Community Engagement Universitas Indonesia through the program Hibah Publikasi Internasional Terindeks untuk Tugas Akhir Mahasiswa (Hibah PITTA) - No 2186/UN2.R3.1/HKP.05.00/2018.

Ethical approval: This study has obtained ethical approval from the Ethics Committee of Faculty of Public Health, Universitas Indonesia No. 253/UN2.F10/PPM.00.02/ 2018

Received for publication: 27 June 2020

Revision received: 30 September 2021.

Accepted for publication: 1 October 2021.

This work is licensed under a Creative Commons Attribution-NonCommercial 4.0 International License (CC BY-NC 4.0).

(C) Copyright: the Author(s), 2021

Licensee PAGEPress, Italy

Italian Journal of Food Safety 2021; 10:9215 doi:10.4081/ijfs.2021.9215

Priok with the total of 72 foodservice facilities. They are Tanjung Priok Main Port (33 foodservice facilities), Sunda Kelapa Seaport and Marina Ancol Beach (3 foodservices facilities), Marunda Sea Port (9 foodservice facilities), and Kalibaru Seaport (27 foodservice facilities). The type 
of foodservice facilities can be as a restaurant, canteen, and street food. In restaurant and canteen, at least they have two employees and open at different times. They are open 24 hours, 07.00a.m.-04.00p.m., 12.00a.m.-08.00p.m. In the restaurant/canteen at least they have five menus every day.

The food management place has potential for food contamination and cause some diseases. The role of the port health office is very important to prevent the entry and exit of food-borne infectious diseases as a border. A study in the three Italia inter-national airports investigated facilities to assess the hygienic $d$ in three Italian inter-national airports found high contamination by Total Coliform in particular groups (Balzaretti and Marzano, 2013). The data obtained from the Port Health Office in 2017 showed that from the 233 food samples found in the food-management facility of this port, 35 were contaminated with Escherichia coli (Kantor Kesehatan Pelabuhan I Jakarta, 2017). Another study results showed that 1 $(1,40 \%)$ from 72 food samples contaminated with Staphylococcus aureus bacteria (Putri, 2018). Meanwhile, contamination with this bacterial indicates exposure to human fecal material caused by inadequate hygiene and sanitation during food management (F.D.A., 2018). Then it suggested that more effort is needed in the application of HACCP principles (Balzaretti and Marzano, 2013).

Food handlers have an important role in preventing food contamination that can develop into foodborne disease outbreaks. To prevent food contamination, food handlers who work at kitchen premises in the port must handle food properly. This study aimed to evaluate the knowledge, attitudes, and food handling practices regarding food safety and personal hygiene among food handlers at kitchen premises in the Port ' $\mathrm{X}$ ' area in North Jakarta, Indonesia.

\section{Materials and methods}

\section{Study design and location}

This is a cross-sectional study. The research was conducted at restaurant kitchen premises located in the Port ' $\mathrm{X}$ ' area in North Jakarta, Indonesia, from April 2018 to May 2018. The research location was in the restaurant, under the Tanjung Priok Class I Port Health Office, Jakarta, Indonesia which is the largest and busiest port in Indonesia. To comply with the research's ethical consideration, the authors intended to give an initial ' $\mathrm{X}$,' as it aims to keep the actual name of this place secret.
Nonetheless, its real name is the Tanjung Priok Class I Port Health Office, Jakarta.

\section{Study population and samples}

The population used were obtained from 72 Food Management Places (Indonesian: Tempat Pegelolaam Makanan) spread across four working areas, including food handlers, and all food produced in the study area. Nonetheless, the samples selected were 72 food handlers working in the various restaurants' kitchen premises, found in the study location.

The minimum sample was determined using the formula for the hypothesis test, with different proportions (Lemeshow, 1997), based on the previous study (Zulaikhah and Karlina, 2010; Sugiyono, 2009).

$$
n=\frac{\left(z_{1-\alpha / 2} \sqrt{2 \bar{P}(1-\bar{P})}+z_{1-\beta} \sqrt{P_{1}\left(1-P_{1}\right)+P_{2}\left(1-P_{2}\right)}\right)^{2}}{\left(P_{1}-P_{2}\right)^{2}}
$$

\section{Description:}

\section{n: Minimum sample size required}

Z1-a/2: Z-value 1.96 at 2-sided confidence level $5 \%$

Z1- $\beta$ : Z-value at test strength (90\%)

P1: The proportion of food contaminated with Staphylococcus aureus that has risk factors

P2: The Proportion of food not contaminated with Staphylococcus aureus that has no risk factors

Based on the test formula, the minimum sample was 17. However, because this study used a hypothesis test with different proportions, the number of samples was obtained by doubling the minimum number; therefore, it was 34 . This research used the total population, which was 72 food handlers.

This study used purposive sampling, a type of Non-Random Sampling, for selecting samples while following the inclusion and exclusion criteria. The inclusion criteria were a) being willing to be a respondent by signing the informed consent, and $\mathrm{b}$ ) being an active and continuous worker at the Food Management Place. Simultaneously, the exclusion criteria were not being at the study location during the study period.

The sample that selected was the total population (all restaurant kitchen premises and food handler representation who working at restaurant kitchen premises located in the Port ' $\mathrm{X}$ ' area in North Jakarta, Indonesia). In total, 72 food handlers participated in this study. Data was collected using questionnaires and checklists through interviews and observations.

\section{Questionnaire and observation checklist}

The questionnaire used in this study was divided into four parts. The first part collected socio-demographic data from the food handlers, such as gender, age, level of education, and food safety training attended. The second part, consisting of 20 questions, collected knowledge data. Each question in this section was given two answer choices - "correct" and "incorrect." The correct answer was coded as 1 , and the wrong statement was coded as 0 . The third part, consisting of 13 questions, collected attitude data. Each question in this section included four answer choices - "strongly disagree," "disagree," "agree," and "strongly agree." The answer "strongly disagree" was coded as 0 , "disagree" was coded as 1 , "agree" was coded as 2 , and "strongly agree" was coded as 3 . The last part of the questionnaire collected data about the food handling practices of food handlers, based on observations.

Observations were done for one day during the interview, the food handlers did not know if they were being observed but the statement like "food handlers showered two times per day" was asked by food handlers. This section consisted of 22 statements, and each statement was given two answer choices - "yes" and "no." The answer "yes" was coded as 1 , and "no" was coded as 0 . The questionnaire used in this study was designed based on previous food safety studies (Ansari-Lari, 2010; Sani and Siow, 2014; Siau, Son and Mohhiddin, 2015; Soares, 2012.

\section{Data collection}

Data were collected face-to-face interviews using a questionnaire and direct observation checklists. The questionnaire was used to investigate the following variables: knowledge, attitudes, and behaviors of food handlers towards personal hygiene, hygiene and sanitation of cooking utensils, and food processing. Furthermore, data was also obtained through observations, using the checklist on the above behavioral variables of food handlers and the environment where the food management was carried out.

Before the interviews and observations, the respondent was given a vivid explanation about the study's implementation by handing them the explanatory text to read. Furthermore, they were asked to give their consent to become subjects by signing informed consent. The researcher conducted the interview and observation.

\section{Statistical analysis}

The data collected from food handlers were converted to frequency and percent- 
age. The correlation Pearson test was used to determine the relationship between the scores for knowledge, attitudes, and practices of food handlers, and an independent $t$ test was used to determine the average score differences for knowledge, attitudes, and practices of food handlers based on sociodemographic conditions such as gender, level of education, and food safety training of food handlers.

\section{Results and discussion}

The socio-demographic characteristics of the respondents in this study are shown in Table 1. The largest groups of respondents were women $(70.80 \%)$, individuals aged 41-47 years $(26.40 \%)$, high school and junior high school graduates (tied at $31.90 \%$ each), and those who have never attended food safety training $(63.60 \%)$.

\section{Knowledge}

Overall, knowledge of food safety is divided into four categories: personal hygiene, time and temperature control, foodborne diseases, and cross-contamination. Figure 1 presents the knowledge level of the food handlers. The mean score of knowledge was 12.38 (Standard Deviation $=$ 2.82). Most respondents correctly answered questions about personal hygiene (85.9\%). Respondents also had good knowledge regarding cross-contamination $81.9 \%$ ) and time and temperature control $(70.85 \%)$. However, respondents had poor knowledge regarding foodborne diseases (39.81\%). Table 2 details the food safety knowledge questions and the food handlers' responses. These results are in line with Sani et al. in Malaysia (Sani and Siow, 2014), which found that research participants had a good knowledge of personal hygiene, but contrary to study in Saudi Arabia (Al-Shabib and Mosi, 2016), which found research participants to have better knowledge about foodborne diseases.

In the present study, $86.10 \%$ of food handlers did not know that the $S$. aureus is one of the germs that cause foodborne diseases. A total of $51.40 \%$ of food handlers did not know that $S$. aureus is not a germ that causes typhoid fever, $80.60 \%$ did not know that contamination of $S$. aureus in food can occur if food handlers do not wash their hands before processing food, and $84.70 \%$ did not know that contamination of $S$. aureus in food can occur when food handlers sneeze or cough toward food when processing it. This is in line with research which found that as many as 50\% of food handlers studied in Brazil did not know that $S$. aureus is one of the germs that cause foodborne diseases (Soares, 2012); McLaughlin et al. (2008), which found that $24 \%$ of research respondents had never heard of the $S$. aureus bacteria (McLaughin, no date); Ansari-Lari et al. (2010), which found that $67 \%$ of research respondents did not know that $S$. aureus is a pathogenic bacterium that is the cause of foodborne diseases (Ansari-Lari, 2010); and Gould et al. (2009), which found that $40 \%$ of research respondents did not know how the $S$. aureus bacteria spread (Gould, 2009).

Besides, the current study found that as many as $76.4 \%$ of food handlers did not know that Salmonella typhii (S. typhii) is a pathogen that can cause foodborne diseases, $50 \%$ did not know that $S$. typhii is a germ that causes typhoid fever, and $59.7 \%$ did not know that food hygiene can affect the occurrence of foodborne diseases. The opposite results were reported by research conducted in Malaysia, which found that $73.4 \%$ of the food handlers studied had good knowledge regarding foodborne pathogens (Abdul-Mutalib et al., 2012).

These results suggest that the Port ' $\mathrm{X}$ ' Health Office and all its work areas should add curriculum material about other pathogenic bacteria, in addition to the

Table 1. Demographic characteristics of respondents.

\begin{tabular}{lcccc} 
Characteristics & Frequency & Percentage (\%) & MeantSD & Range \\
Age (years) & & & $41.57+11.28$ & $20-67$ \\
$20-26$ & 7 & 16.7 & \\
$27-33$ & 12 & 19.4 & \\
$34-40$ & 14 & 26.4 & \\
$41-47$ & 19 & 15.3 & \\
$48-54$ & 11 & 6.9 & \\
$55-61$ & 5 & 5.6 & \\
62-68 & 4 & & \\
Education level & & 9.7 & \\
No formal education & 7 & 23.6 & \\
Elementary school & 17 & 31.9 & \\
Junior high school & 23 & 31.9 & \\
High school & 23 & 2.8 & \\
University & 2 & & \\
\hline Gender & & 70.8 & \\
Female & 51 & 29.2 & \\
Male & 21 & & \\
Food safety training & & 36.1 & \\
Yes & 26 & 63.9 & \\
No & 46 & 100.0 & \\
Total & 72 & & \\
& & & \\
\hline
\end{tabular}

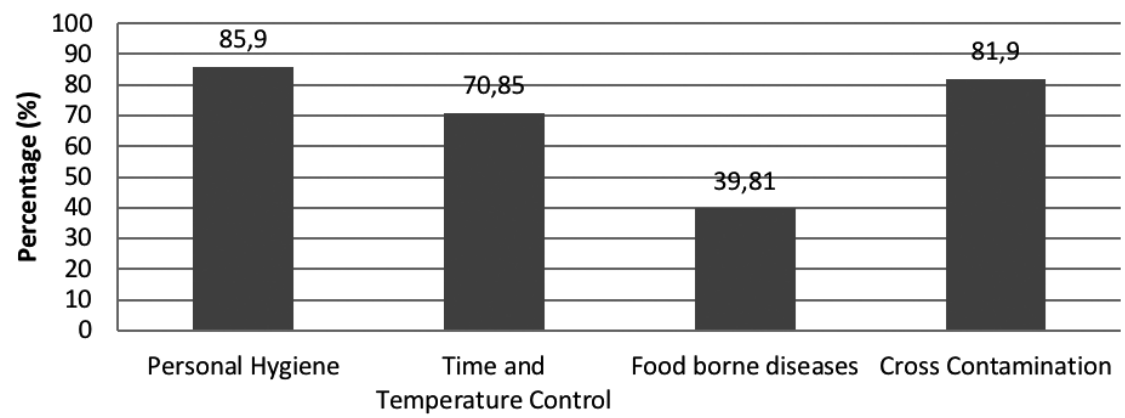

Types of Knowledge

Figure 1. Food handlers' correct responses (\%) by knowledge category. 
Escherichia coli (E. coli) bacteria, when food safety training is conducted. Training is an effective tool to increase the food safety knowledge of food handlers (Gillespie, Little and Mitchell, no date). The distribution of food handlers' knowledge about food safety can be seen in detail in Table 2 .

\section{Attitudes}

The mean score of attitudes was 25.50 (Standard Deviation $=3.64)$. Attitudes about food safety are important factors that can influence food handling practices among food handlers (Sani and Siow, 2014). According to the results of the present study, $56.90 \%$ of food handlers stated that they did not want to attend food safety training. They did not have the time to attend the training activities because they had to cook and sell food from morning to night. As a possible solution, the Port ' $\mathrm{X}$ ' Health Office and its work areas could conduct hygiene and sanitation training in the afternoon, under the assumption that the food cafeteria has fewer customers at this time. The training is important not only to instruct food handlers on how to handle and cook food properly but also to improve the knowledge and attitudes of the food handlers regarding food safety (NietoMontenegro, Brown and LaBorde, 2008). The formal training provided by the health office is about the right food handling and personal hygiene that must be held by food handlers. So, the management should comply with the regulation that the food handler must regularly take the formal training provided.

Of the respondents, $47.20 \%$ agreed that raw materials and leftover food can be stored in the same part of the refrigerator. These food handlers generally place leftover food into refrigerators in containers that are not closed, and they place the leftover food in the same part of the refrigerator as the raw materials. However, leftover food and raw materials should be stored in separate places to avoid contamination from raw materials to leftover foods (Government of South Australia, 2013). Food handlers who work in kitchen premises should store leftover food in a closed container before it is put in the refrigerator. The distribution of respondents' attitudes about food safety can be seen in Table 3 .

\section{Practices}

The mean score of practice was 14.58 (Standard Deviation $=1.84)$. Based on some indicators, statements submitted to respondents regarding the food handlers' hygiene indicated most of the respondents exhibited poor behaviors in six statements of food safety. Mostly, $54.20 \%$ food handlers washed their hands without using soap because there was no soap for handwashing at the sink. Hands should be cleaned using liquid soap, while avoiding or limiting the use of bar soap because it can be a hiding

Table 2. Knowledge of food handler regarding food safety.

\begin{tabular}{|c|c|c|c|c|c|}
\hline \multirow[t]{2}{*}{ No. } & \multirow[t]{2}{*}{ Statement/question } & \multicolumn{2}{|c|}{ Correct } & \multicolumn{2}{|c|}{ Incorrect } \\
\hline & & n & $\%$ & n & $\%$ \\
\hline \multicolumn{6}{|c|}{ Personal hygiene } \\
\hline 1. & Food must be stored in a closed container. (Yes) & 67 & 93.10 & 5 & 6.90 \\
\hline 2. & Storage of several types of food dishes can be mixed in one container.* (No) & 63 & 87.50 & 9 & 12.50 \\
\hline 3. & Using a mask, head cover, gloves can reduce the risk of contamination of food. (Yes) & 68 & 94.40 & 4 & 5.60 \\
\hline 4. & Using clean clothes while doing food processing activities cannot reduce the risk of contamination of food.* (No) & 39 & 54.20 & 33 & 45.80 \\
\hline 5. & Hand washing before starting food processing activities can reduce the risk of contamination of food. (Yes) & 67 & 93.10 & 5 & 6.90 \\
\hline 6. & $\begin{array}{l}\text { Maintaining the cleanliness of the environment where food is managed (such as refrigerators, hand washing } \\
\text { stations, floors, etc.) can reduce the risk of food poisoning to consumers. (Yes) }\end{array}$ & 67 & 93.10 & 5 & 6.90 \\
\hline \multicolumn{6}{|c|}{ Time and temperature control } \\
\hline 7. & $\begin{array}{l}\text { The refrigerator temperature used to store food containing protein (fish, beef, chicken, etc.) } \\
\text { must be above } 5^{\circ} \mathrm{C} .{ }^{*} \text { (No) }\end{array}$ & 48 & 66.70 & 24 & 33.30 \\
\hline 8. & $\begin{array}{l}\text { The cooking temperature must be at least } 90^{\circ} \mathrm{C} \text { so that the pathogenic germs die, and it must not be cooked too } \\
\text { long so that the nutrients are not lost due to evaporation. (Yes) }\end{array}$ & 62 & 86.10 & 10 & 13.90 \\
\hline 9. & Gravy foods must be served immediately at temperatures above $60^{\circ} \mathrm{C}$. (Yes) & 55 & 76.40 & 17 & 23.60 \\
\hline 10. & $\begin{array}{l}\text { Cold food should be served at temperatures lower than } 4.4^{\circ} \mathrm{C} \text { to avoid contamination of food from } \\
\text { pathogenic germs. (Yes) }\end{array}$ & 39 & 54.20 & 33 & 45.80 \\
\hline
\end{tabular}

11. Food storage in an open place can cause health hazards to buyers/consumers. (Yes)

12. Diarrhea can be transmitted through food. (Yes)

13. S. aureus is one of the germs that cause foodborne illness. (Yes)

14. S. aureus is a bacteria that causes typhoid fever.* (No)

15. Contamination of $S$. aureus in food can occur if food handlers do not wash their hands before starting food management. (Yes)

16. Contamination of $S$. aureus in food can occur when food handlers sneeze or cough toward food. (Yes)

17. Salmonella typhii (S. typhii) is one of the germs that cause foodborne illness. (Yes)

18. S. typhii is a bacteria that causes typhoid fever. (Yes)

19. Food and beverage cleanliness does not affect the occurrence of foodborne diseases.* (No)

$\begin{array}{cccc}64 & 88.90 & 8 & 11.10 \\ 60 & 83.30 & 12 & 16.70 \\ 10 & 13.90 & 62 & 86.10 \\ 35 & 48.60 & 37 & 51.40 \\ 14 & 19.40 & 58 & 80.60\end{array}$

Cross-contamination

20. Cross contamination is the main factor causing food poisoning. (Yes)

$59 \quad 81.90 \quad 13$


place for bacteria that can contaminate food (Kadariya, Smith and Thapaliya, 2014). If food handlers want to use bar soap, it should be stored in a container that drains excess water away from the bar, and the container must be cleaned regularly. Also, $69.40 \%$ of food handlers washed their hands without using running water. In the port area, access to clean water is very limited, so food handlers must supply their clean water needs by buying containers of water from hucksters. Inadequate food handling practices are a major cause of food contamination, and clean water is the main substance needed for necessities such as washing hands, washing food, cleaning food processing facilities, and washing equipment used to eat and cook (Commissions Codex Alimentarius, 2003).

Ready-to-eat food must be free from physical, chemical, and biological contamination. Physical contamination includes foreign objects such as hair, broken glass, gravel, sticks, and metal. To prevent these contaminations in food, food handlers must use equipment like caps, aprons, and gloves (Kementerian Kesehatan Republik Indonesia, 2011). However, the results of the current study show that $90.30 \%$ of food handlers did not use aprons when processing food and $80.60 \%$ did not use head coverings during food processing activities, both of which could be sources of physical contamination in food. These results are in line with Ansari-Lari et al. (2010), which revealed that only $56.5 \%$ of the studied food handlers always used a cap or head covering when processing food (Ansari-Lari, 2010). To prevent food contamination, especially from the $S$. aureus bacteria, food handlers should avoid contact with cooked food as much as possible to prevent contamination (Hennekinne, Buyser and Dragacci, 2012). However, the results of the present study showed that $98.60 \%$ of food handlers did not use masks during the production or presentation of food, and as many as $98.60 \%$ did not use gloves when processing food. These conditions are potential sources of biological contamination in food by $S$. aureus from food handlers who are carriers of the bacteria. Ortega suggested that contamination of $S$. aureus generally occurs in food after the heating process (Ortega and Abriouel, 2010). This usually occurs when food handlers who are carriers of the $S$. aureus bacteria intentionally or unintentionally make direct contact with food, such as touching the food or coughing and sneezing toward the food. To prevent contamination, the handler should avoid contact with cooked food as much as possible. The advice for port managers is to provide access to clean, running water that flows to every food-management located in the port. The advice for food handlers is to wash their hands using soap and to use aprons, head coverings, and gloves when managing food to prevent physical, chemical, and biological contamination of food. The distribution of food handling practices of food handlers can be seen in Table 4 .

\section{Correlations among socio-demo- graphics, knowledge, attitudes, and practices}

The results of this study indicate that there is a significant relationship between the level of knowledge and attitude of the handler $(p=0.01)$. This is in line with Sani et al. (2014), which found that the level of knowledge about food safety is correlated to the attitude of the food handler regarding food safety. However, no relationship was found between the level of knowledge and the food handling practices of the food handler $(p=0.113)$, nor between attitudes and food handling practices $(p=0.889)$ in the current study. These results are in line with two studies (Clayton, Griffith and Peters, 2002) and (Pilling, Brannon and Shanklin, 2008), which found that food handlers who have good food safety knowledge rarely apply their knowledge when handling food.

Attitude scores in the present study were significantly higher among food handlers who reported attending a previous food safety training course $(p=0.002)$, with $(r=0.302)$ it means a weak uphill (positive) linear relationship attitude scores and raining that food handler attended. Attitude is an important factor, in addition to the

Table 3. Attitudes of food handlers regarding food safety.

\begin{tabular}{|c|c|c|c|c|c|c|c|c|c|}
\hline No. & Statement & ongl & agree & & ree & & & Stron: & agree \\
\hline & & n & $\%$ & n & $\%$ & n & $\%$ & n & $\%$ \\
\hline 1. & Food handlers are responsible for preventing food poisoning. (Agree) & 26 & 36.10 & 43 & 59.70 & 3 & 4.20 & 0 & 0.00 \\
\hline 2. & $\begin{array}{l}\text { Maintaining an environment where food is kept clean is the best way to } \\
\text { prevent food poisoning. (Agree) }\end{array}$ & 25 & 34.70 & 43 & 59.70 & 4 & 5.60 & 0 & 0.00 \\
\hline 3. & $\begin{array}{l}\text { I will read more books to increase knowledge about food hygiene } \\
\text { and safety. (Agree) }\end{array}$ & 18 & 25.00 & 41 & 56.90 & 13 & 18.10 & 0 & 0.00 \\
\hline 4. & $\begin{array}{l}\text { Training on food safety is important to improve my knowledge and ability } \\
\text { to process clean and safe food for my customers. (Agree) }\end{array}$ & 18 & 25.00 & 49 & 68.10 & 5 & 6.90 & 0 & 0.00 \\
\hline 5. & $\begin{array}{l}\text { I do not want food safety training, because I don't have time } \\
\text { to attend training.* (Disagree) }\end{array}$ & 1 & 1.40 & 41 & 56.90 & 28 & 38.90 & 2 & 2.80 \\
\hline 6. & $\begin{array}{l}\text { I should not perform food processing activities with injured hands. } \\
\text { (Agree) }\end{array}$ & 14 & 19.40 & 46 & 63.90 & 12 & 16.70 & 0 & 0.00 \\
\hline 7. & $\begin{array}{l}\text { Meat, fish, and chicken should be stored at temperatures } \\
\text { below }-10^{\circ} \mathrm{C} \text { if they will be stored for more than a week. (Agree) }\end{array}$ & 4 & 5.60 & 49 & 68.10 & 17 & 23.60 & 2 & 2.80 \\
\hline 8. & $\begin{array}{l}\text { Raw materials and leftover food can be stored in the same part in } \\
\text { the refrigerator.* (Disagree) }\end{array}$ & 5 & 6.90 & 34 & 47.20 & 31 & 43.10 & 2 & 2.80 \\
\hline 9. & $\begin{array}{l}\text { I can use the same cloth to dry my hands, clean my hands, and wipe } \\
\text { or dry the dishes.*(Disagree) }\end{array}$ & 12 & 16.70 & 24 & 33.30 & 34 & 47.20 & 2 & 2.80 \\
\hline 10. & I should touch my face, hair, etc. during food processing activities. (Agree) & 11 & 15.30 & 53 & 73.60 & 8 & 11.10 & 0 & 0.00 \\
\hline 11. & I should touch my face, hair, etc. during food processing activities. (Agree) & 16 & 22.20 & 54 & 75.00 & 2 & 2.80 & 0 & 0.00 \\
\hline 12. & $\begin{array}{l}\text { I have to wash my hands after covering my mouth and nose while } \\
\text { coughing or sneezing. (Agree) }\end{array}$ & 13 & 18.10 & 58 & 80.60 & 1 & 1.40 & 0 & 0.00 \\
\hline 13. & I should not work with a dirty hand. (Agree) & 21 & 29.20 & 47 & 65.30 & 4 & 5.60 & 0 & 0.00 \\
\hline
\end{tabular}


Table 4. Food handling practices.

1. Handler carries out food processing activities while suffering from infectious diseases such as skin diseases, boils, open wounds, and upper respiratory tract infections (URTI).* (No)

2. Handler showers at least two times a day (Yes)

3. Handler's teeth are brushed at least two times a day. (Yes)

4. Handler wipes off sweat during the food production process or when serving food. (If not cooking, just ask.)* (No)

5. Handler picks his ear(s) during the food production process or when serving food. (If not cooking, just ask.)* (No)

6. Handler picks his nose during the food production process or when serving food. (If not cooking, just ask.)* (No)

7. Handler coughs or sneezes in the direction of food when performing food processing activities. (If not cooking, just ask.)* (No)

8. Handler washes his hands before work or after using the toilet. (Check availability of handwashing soap at the handwashing station and presence of running water.) (Yes)

9. The handler uses soap to wash his hands. (Check availability of soap at the handwashing station.) (Yes)

10. Handler washes his hands in running water. (Check if there is running water in the handwashing area.) (Yes)

11. Handler has clean fingernails. (Yes)

12. Handler's fingernails are not long. (Yes)

13. The handler is free of cosmetics, such as eye shadow, powder, and nail polish. (Yes)

14. The handler does not wear jewelry, such as rings, earrings, or necklaces (Yes)

15. Handler always changes work clothes with clean garments. (Yes)

16. The handler uses an apron. (Yes)

17. Handler wears clean clothes. (Yes)

18. Handler wears footwear. (Yes)

19. The handler uses a headcover. (Yes)

20. Handler smokes during the food production or presentation processes. (Ask whether the handler is a smoker.) *(No)

21. The handler uses a mask covering the mouth and nose during the food production process or when serving food. (Yes)

22. The handler uses gloves when performing food processing activities. (Yes)

$\begin{array}{cccc}3 & 4.20 & 69 & 95.80 \\ 72 & 100.00 & 0 & 0.00 \\ 72 & 100.00 & 0 & 0.00 \\ 22 & 30.60 & 50 & 69.40 \\ 3 & 4.20 & 69 & 95.80 \\ 2 & 2.80 & 70 & 97.20 \\ 5 & 6.90 & 67 & 93.10\end{array}$

$40 \quad 55.60 \quad 32$

\begin{tabular}{cccc}
33 & 45.80 & 39 & 54.20 \\
22 & 30.60 & 50 & 69.40 \\
71 & 98.60 & 1 & 1.40 \\
69 & 95.80 & 3 & 4.20 \\
37 & 51.40 & 35 & 48.60 \\
37 & 51.40 & 35 & 48.60 \\
70 & 97.20 & 2 & 2.80 \\
7 & 9.70 & 65 & 90.30 \\
66 & 91.70 & 6 & 8.30 \\
61 & 84.70 & 11 & 15.30 \\
8 & 11.10 & 64 & 88.90 \\
14 & 19.40 & 58 & 80.60 \\
1 & 1.40 & 71 & 98.60 \\
1 & 1.40 & 71 & 98.60 \\
\hline
\end{tabular}

Table 5. Correlations among food handlers' socio-demographics, knowledge, attitudes, and practices.

\begin{tabular}{|c|c|c|c|c|c|}
\hline Level & Test & p-value & $\mathbf{r}$ & Mean & Standard deviation \\
\hline Knowledge-attitudes & Correlation test & 0.010 & 0.302 & & \\
\hline Knowledge-practices & Correlation test & 0.113 & 0.189 & & \\
\hline Attitudes-practices & Correlation test & 0.889 & 0.017 & & \\
\hline Education-knowledge & Independent $t$-test & 0.213 & - & 12.96 & 2.993 \\
\hline Sex-knowledge & Independent $t$-test & 0.797 & - & 12.52 & 2.421 \\
\hline Training-knowledge & Independent $t$-test & 0.169 & - & 13.00 & 2.786 \\
\hline Sex-attitude & Independent $t$-test & 0.848 & - & 0.53 & 0.512 \\
\hline Education-attitudes & Independent $t$-test & 0.080 & - & 0.40 & 0.500 \\
\hline Training-attitudes & Independent $t$-test & 0.002 & - & 0.31 & 0.471 \\
\hline Education-practices & Independent $t$-test & 0.071 & - & 15.12 & 1.787 \\
\hline Sex - practice & Independent $t$-test & 0.279 & - & 14.95 & 2.037 \\
\hline Training-practices & Independent $t$-test & 0.583 & - & 14.42 & 1.678 \\
\hline
\end{tabular}


knowledge and regulations that apply in reducing the incidence of foodborne diseases because good attitudes and knowledge can influence the continuity of proper food handling practices (Saniler, 2017). Research conducted in Malaysia has shown a relationship between the level of education and food processing training and the knowledge and attitudes of food handlers about food safety (Lee, Halim and Thong, 2017). This shows that periodic food safety training is needed so that food handlers can demonstrate the food safety knowledge they learned in training when handling food. This is beneficial because the knowledge gained from training can be translated into attitudinal and behavioral changes (National Restaurant Association Educational Foundation, 1992) (Table 5).

There are many pieces of research measuring KAP food handler, which usually conducted in a restaurant, catering, or any canteen in public places. This research conducted in a port, which is a specific place that serves passengers or travelers. The question was the focus on $S$. aureus. This bacterium rarely investigated since some research usually conducted for $E$. coli bacteria. From these KAP findings, food contamination especially by harmful bacteria, S. aureus, can be prevented for passengers or travelers. Since there was only a measure of the KAP among food handlers, furthermore studies needed to investigate the contamination of $S$. aureus bacteria and other contamination on food and beverages sold in the food stall around the port. Also, the questionnaires developed and constructed from any resources such as regulation, standards, codex, etc.

Information bias may occur when the respondent asked about the knowledge of $S$. aureus. It is possible the food handler never knows or never heard about these bacteria. According to the calculation of the sample, it seems this sample is too small, to anticipate the representativeness of the population, then the total population (72) used in this research. This study did not investigate the episodes of MTA food poisoning. We thought this is one of our limitations as well, so we advise doing further research to cover MTA food poisoning; Further research also suggested using the proper number of samples to represent the actual population in the port.and research conducted in any kind of port, such as airport, seaport either small or big port.

\section{Conclusions}

Overall, food handlers have a good knowledge regarding personal hygiene, cross-contamination, and time and temperature control, but the respondents had poor knowledge regarding foodborne diseases. Almost half of the food handlers stated that they did not want to attend food safety training because they did not have the time for training activities since they had to cook and sell food all day. Also, access to clean water in the port is very limited, this situation means that food handlers cannot perform necessary personal hygiene activities, such as washing hands, washing food, and cleaning and washing cooking equipment. This study found a significant relationship between the knowledge and attitude of food handlers, but there was no significant relationship between knowledge or attitude and food handling practices.

To have a good practice, the foodhanler should to have a time to take a training facilitate by the port. Training activities must be held routinely among the food handlers because there is a significant relationship between food safety training and the handlers' attitudes toward the application of food safety. Knowledge of food safety obtained from training can translate into improved attitudes and better food handling practices to provide safe food management for consumers. Further research suggested using the proper number of samples to represent the actual population in the port. Also, research conducted in any kind of port, such as airport, seaport either small or big port.

\section{References}

Abdul-Mutalib NA, Abdul-Rashid MF, Mustafa S et al, 2012. Knowledge, attitude and practices regarding food hygiene and sanitation of food handlers in Kuala Pilah, Malaysia. Food Control 27:289-93.

Al-Shabib NA, Mosi SH, 2016. A cross-sectional study on food safety knowledge, attitude, and practices of male food handlers employed in restaurants of King Saud University, Saudi Arabia. Food Control 59:212-17.

Angelillo I, Viggiani N, Rizzo L, 2000. Food handlers and foodborne diseases: Knowledge, attitudes, and reported behavior in Italy. J Food Protect 53:381-5.

Ansari-Lari M, 2010. Knowledge, attitudes and practices of workers on food hygienic practices in meat processing plants in Fars, Iran. Food Control 21:260-3.

Arnita D, 2014. Strategy Port of Tanjung Priok as an International Hub Port: Comparative Study of the Port of Singapore. Institut Pertanian Bogor.
Balzaretti CM, Marzano MA, 2013. Prevention of travel-related foodborne diseases: Microbiological risk assessment of food handlers and ready-to-eat foods in northern Italy airport restaurants. Food Control 29:202-7.

Bou-Mitri C, Mahmoud D, El Gerges N, 2018. Food safety knowledge, attitudes and practices of food handlers in Lebanese hospitals: A cross-sectional study. Food Control 94:74-84.

Clayton D, Griffith C, Peters A, 2002. Food handlers' beliefs and self-reported practices. Int J Environ Health Res 12:2539.

Commissions Codex Alimentarius, 2003. Recomended international code of practice general principles of food hygiene. CAC/RCP, Rev, 4, pp. 1-1969.

EFSA, 2010. European Food Safety Authority European Food SThe community summary report on trends and sources of zoonoses, zoonotic agents and food-borne outbreaks in the European Union in 2008. The EFSA J 8:1-131.

Gillespie I, Little C, Mitchell R. Microbiological examination of cold ready-to-eat sliced meats from catering establishments in the United Kingdom. J Appl Microbiol 88:467-74.

Gould D, 2009. Patients and the public: knowledge, sources of information and perceptions about healthcare-associated infection. J Hosp Infect 72:1-8.

Government of South Australia (2013) HELLPP (Healthy Eating Local Policies Programs), Government of South Australia, \& Flinders University. South Australia: Government of South Australia.

Hennekinne JA, Buyser ML, Dragacci S, 2012. Staphylococcus aureus and its food poisoning toxins: characterization and outbreak investigation. FEMS Microbiol 36:815-36.

Kadariya J, Smith TC, Thapaliya D, 2014. Staphylococcus aureus and Staphylococcal Food-Borne Disease: An Ongoing Challenge in Public Health. BioMed Res Int 1-9.

Kantor Kesehatan Pelabuhan I Jakarta, 2017. Data Jejaring Surveilens Epidemiologi Kantor Kesehatan Pelabuhan X dengan Sarana Pelayanan Kesehatan Tahun 2017.

Kemenkes RI, 2011. Peraturan Menteri Kesehatan Republik Indonesia Nomor 2348 / MENKES/PER/X I/ 2011 tentangPerubahan atas Peraturan Menteri Kesehatan RI Nomor $356 /$ M ENKE S / P E R/I V / 2008 Organisasi dan Tata Kerja Kantor Kesehatan Pelabuhan. pp. 1-19. 
Kementerian Kesehatan Republik Indonesia (2011) 'Peraturan Menteri Kesehatan Republik Indonesia Nomor 1096/MENKES/PER/VI/2011 Tentang Higiene Sanitasi Jasaboga'.

Kirk MD, 2015. World Health Organization Estimates of the Global and Regional Disease Burden of 22 Foodborne Bacterial, Protozoal, and Viral Diseases, 2010: A Data Synthesis. PLoS Med 12:1-21.

Lee HK, Halim HA, Thong KL, 2017. Assessment of Food Safety Knowledge, Attitude, Self-Reported Practices, and Microbiological Hand Hygiene of Food Handlers. Environ Res Public Health 14:1-14.

Lemeshow S, 1997. Besar Sampel Penelitian Kesehatan terjemahan Dibyo Pramono. Yogyakarta: Gajah Mada University Press.

McLaughin A, Canavan JB, Adams EJ, et al, 2008. A survey of MRSA awareness and knowledge among the general public and patients' visitors. J Infect Control 9:18-23.

Medeiros L, Hillers V, Chen G, 2004. Design and development of food safety knowledge and attitude scales for consumer food safety education. J Am Diet Assoc 104;1671-7.

National Restaurant Association Educational Foundation, 1992. Educational Foundation of the National Restaurant Association. 4th edn. Canada: John Wiley and Sons.

Nieto-Montenegro S, Brown J, LaBorde L,
2008. Development and assessment of pilot food safety educational materials and training strategies for Hispanic workers in the mushroom industry using the health action model. Food Control 19:616-33.

Ortega E, Abriouel H, 2010. Multiple Roles of Staphylococcus aureus Enterotoxins: Pathogenicity, Superantigenic Activity, and Correlation to Antibiotic Resistance. Toxin J 2:2117-31.

Pilling V, Brannon L, Shanklin C, 2008. Identifying specific beliefs to target to improve restaurant employees' intentions for performing three important food safety behaviors. J Am Diet Assoc 108:991-7.

Putri MS, 2018. Kontaminasi Staphylococcus aureus pada Makanan di Tempat Pengelolaan Makanan Wilayah Kerja Kantor Kesehatan Pelabuhan X di Jakarta Utara Tahun 2018 Tesis Program Studi Ilmu Kesehatan Masyarakat Kekhususan/ Departmen Kesehatan Lingkungan Depok. Universitas Indonesia.

Sani NA, Siow ON, 2014. Knowledge, attitudes and practices of food handlers on food safety in food service operations at the Universiti Kebangsaan Malaysia. Food Control 37:210-7.

Saniler N, 2017. Food safety knowledge, attitude and food handling practices of students. Br Food J 470-9.

Scallan E, Hoekstra MR, 2011. Foodborne Illness Acquired in the United Statesmajor Pathogens. Emerg Infect Dis
17:7-15.

Sharif L, Al-Malki T, 2010. Knowledge, attitude and practice of Taif university students on food poisoning. Food Control 21:55-60.

Siau MF, Son R, Mohhiddin O, 2015. Food court hygiene assessment and food safety knowledge, attitudes and practices of food handlers in Putrajaya. International Food Research Journal, 22, pp. 1843-1854.

Soares L, 2012. Knowledge, attitudes, and practices in food safety and the presence of coagulase-positive. Food Control 206-213.

Sugiyono LP, 2009. Gambaran pengetahuan, sikap dan praktik serta identifikasi bakteri Eschericia coli dan Staphylococcus aureus pada penjamah dan makanan di PT PSA. pp. 1-40.

World Health Organization, 2015. WHO's first ever global estimates of foodborne diseases find children under 5 accounts for almost one-third of deaths. Available from: http://www.who.int/mediacentre/news/releases/2015/foodborne-disease-estimates/en/.

Zanin ML, Cunha TD, 2017. Knowledge, attitudes, and practices of food handlers in food safety: An integrative review. Food Res Int 100:53-62.

Zulaikha ST, Karlina E, 2010. Behavior factors associated with contamination of Staphylococcus aureus bacteria in fast food. pp. 168-175. 